\title{
La position des clitiques par rapport au verbe à l'impératif dans l'évolution du français
}

\section{Paul Hirschbühler}

\section{(2) OpenEdition \\ 12 Journals}

Édition électronique

URL : http://journals.openedition.org/rlv/255

DOI : $10.4000 /$ rlv. 255

ISSN : 1958-9239

Éditeur

Presses universitaires de Vincennes

\section{Édition imprimée}

Date de publication : 1 mai 2001

ISBN : 2-84292-092-9

ISSN : 0986-6124

\section{Référence électronique}

Paul Hirschbühler, «La position des clitiques par rapport au verbe à l'impératif dans l'évolution du français », Recherches linguistiques de Vincennes [En ligne], 30 | 2001, mis en ligne le 06 juin 2005, consulté le 20 avril 2019. URL : http://journals.openedition.org/rlv/255 ; DOI : 10.4000/rlv.255

Ce document a été généré automatiquement le 20 avril 2019

(c) Presses universitaires de Vincennes 


\title{
La position des clitiques par rapport au verbe à l'impératif dans l'évolution du français
}

\author{
Paul Hirschbühler
}

\section{RÉSUMÉS}

Après avoir passé en revue l'évolution de la position des clitiques objets par rapport au verbe conjugué dans l'histoire du français, en particulier dans les impératives, nous étudions les développements les plus récents du français pour les impératives négatives sans ne, ce qui nous permet de mettre en évidence des contrastes qui n'avaient jamais été notés jusqu'ici. L'article propose une analyse de la linéarisation des clitiques par rapport au verbe qui repose en partie sur des propriétés lexicales de ceux-ci. Les changements dans la position des clitiques sont attribués pour une part à des changements dans leurs propriétés lexicales, pour une autre à des changements syntaxiques indépendants.

After having reviewed the evolution of the position of object clitics in the history of French, in particular in imperative clauses, we study the most recent developments in negative imperatives without ne, pointing out facts which had escaped attention to this date. The article proposes an analysis of the linearization of clitics with respect to the verb based in part on lexical properties of the clitics. Changes in clitic position are attributed in part to changes in their lexical properties, in part to independent syntactic changes. 
INDEX

Mots-clés : clitiques objets, diachronie, dialectes du français, histoire du français, mouvement de verbe, optimalité, pronoms

Keywords : impératives, négation, tobler-mussafia, diachrony, french dialects, history of french, object clitics, optimality, pronouns, verb movement 